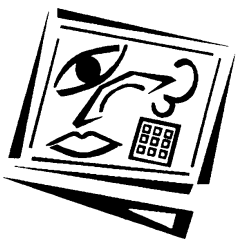

\title{
The impact of blogging on Hong Kong primary school students' bilingual reading literacy
}

\author{
Shek Kam Tse, Allan Hoi Kau Yuen, Elizabeth Ka Yee Loh, Joseph Wai Ip Lam \\ and Rex Hung Wai Ng \\ The University of Hong Kong
}

\begin{abstract}
This study looked at the types of blog consulted by 1,298 Primary 4 students in Hong Kong and whether such consultation influenced performance on standardised tests of Chinese and English reading comprehension. When students were asked if they consulted Chinese and English blogs, 42\% said they looked at Chinese blogs and 19\% said they looked at English blogs. This difference was anticipated since Chinese is the mother tongue of most primary school students in Hong Kong and English is a second language. The themes of sites consulted were categorised into types: the Chinese blogs being able to be categorised into three types, and the English blogs into two. Boys and girls differed in their choice of Chinese and English blog topics and the strength of the students' Chinese and English reading proficiency clearly had some influence on the choice of blogs consulted. Factor analysis was used to group together types of blog and analysis of variance was applied to test differences in performance. With over half of the students saying they did not consult either Chinese or English blogs, it is unwise to draw weighty conclusions about the influence of blogging on reading standards. There was little evidence that regularly consulting the Internet was associated with high grades on either Chinese or English reading tests. Given the large number of students who said they had never consulted blogs, discussion of the analytical outcomes and conclusions are guarded but recommendations are offered.
\end{abstract}

\section{Introduction}

Teachers of literacy worldwide share the task of teaching students to read then giving them practice and coaching in comprehending what other people have written. They also give students practice in expressing their own thoughts in writing and spend many classroom hours painstakingly helping students refine the semantics and syntax of the writing produced. Hopefully, students will move on to using the skills and language conventions acquired to communicate independently with others outside school. The Bullock Report (1975) spoke of schools giving children "A Language for Life" and extended the definition of "literacy" to include reading and writing, and encouraged children to practise expressing their thoughts clearly and succinctly. The Report also noted that parents from high socio-economic groups would, without prompting, offer their children opportunities to read and write at home, and that parents in lower socio-economic groups rarely provided such options for their children at home. The arrival of home computers and mobile phones has done more to redress this discrepancy than many expensively funded projects intended to overcome disadvantages associated with being socially underprivileged. The chance to use sophisticated communication technology is no longer the prerogative of the privileged, it is increasing available to a wide spectrum of society. 
Today's information technology allows children to access information and communicate their thoughts with others instantly and in literary styles that are entirely personal. They also have opportunities to construct their own websites and to share communicative written transactions with others via "blogs". Jorn Barger used the term "weblog" (Barger, 1997; Blood, 2000) in reference to web pages on the Internet in formats that permit "logging" hyperlinks to other web sites. Computer users "surf" such sites searching for items that interest them and soon the term "weblog" was truncated into "blog" (Merholz, 2002). Today, weblogs and blogs are terms used to refer to online sites and journals (Nardi, Schiano, Gumbrecht \& Swartz, 2004). In May 2005, the Blog Herald reported the presence of 60 million blogs worldwide.

The post from blogs is usually updated and arranged in reverse chronological time sequence on the site (Paquet, 2003). There are two key features of blogs: they allow people freedom to edit the blog by adding text, hyperlinks, pictures, video and audio clips and to comment or respond to the post displayed; and they have robust archival features so that blogs and post can automatically be archived, with the public allowed to access, search and retrieve content.

The Hong Kong Census and Statistics Department $(2007 ; 2008)$ reports that the use of blogs is increasing very rapidly in Hong Kong, and that contributors with only modest literacy skills are frequent users. Schools are aware that students are using blogs and are actually meeting the educational objective of being able to use language with confidence to communicate independently with others outside school. Bartlett-Bragg (2003) suggests that blogging can be used positively to enhance the teaching and learning of language, and educational researchers are alert to the need to investigate the impact of the use of blogs by students in Hong Kong on their English and Chinese reading competence. Chen and Zhang (2003) found that encouraging blogging (a) allows teachers and student to share information and ideas and (b) lets others comment or respond to their postings. Such feedback encourages writers to think about how they are expressing themselves, and prompts bloggers to amend and update blogs. Such blog interactions not only encourage students to read and write, they also stimulate thinking. Wu and Chen (2006) found that blogging helps to boost the confidence of computer users to learn independently, to share experiences and ideas through blogs and to contribute, if only in tiny ways, to the construction of knowledge.

Conhaim (2002) proposes that blogging can help learners develop confidence in their ability to learn, confidence that is often flattened in the formal classroom. Confident in their ability to communicate, students voluntarily refine their reading and writing and such improvement is boosted by successes in blog communications. Sim (2008) found that blogging interactions sensitise students to author and reader awareness, the need to use an appropriate communication tone, and to find ways of presenting a case that will be considered seriously and not dismissed out of hand. Sim noted that students' sentence structure, syntax and use of vocabulary showed improvement. Students' attitudes to writing, shaped by numerous episodes of "red pen" responses to what they had written, became more positive. Students' motivation increased, their interest in writing for different purposes grew and apprehensions about expressing themselves in written Chinese receded. Students were much more inclined to consult teachers about ways to express ideas clearly.

Ward (2004) encouraged students to blog and a post-course survey confirmed that students enjoyed the experience, even though they had no prior experience of web 
design. Ward's students' improved their language ability and were much more careful in their writing as a result of knowing that a large readership could look critically at what they had written on the blog. Tan, Teo, Aw and Lim (2005) examined the impact of blog building on students, confirming the impression of others that students' reading and writing improved with blog engagement at a pace greater than that students learning to write in conventional classrooms. In particular, students learnt a great deal from looking at how others expressed ideas and were encouraged to experiment with their writing in the light of positive feedback from their readers.

Blood (2002) found that bloggers, by virtue of simply writing down whatever was on their mind, were confronted by their own thoughts and opinions. Blood argued that daily blogging boosted student confidence in writing, especially since they knew that a community of 100 or 20 or 3 people had access to a public record of their thoughts. Met by friendly readers, students gained in confidence about their view of the world. Some began to experiment with longer forms of writing, some played with haiku and some launched creative projects they would once have dismissed as being inconsequential or beyond their competence only a few months earlier.

Oravec (2002) suggests that writing blogs encourages students to be analytical and critical in several ways. As students actively browse blogs and respond to Internet materials, they delineate their own positions in the context of others' writings and learn how to present their own perspectives on various issues. In addition, constructing and maintaining a blog involves a time commitment and can reinforce in students the importance of persevering with literacy tasks and the value of sustained effort.

As bloggers experience enunciating their opinions daily, an awareness of themselves as people and what they believe in stimulate the development of a rationale for their own perspective. This persuades some to write poetry, to talk about hobbies and obscure interests and to divulge personal beliefs and opinions. Accustomed to expressing thoughts on their website, many bloggers become quite articulate in expressing opinions to others (Bausch, Haughey \& Hourihan, 2002). Many are impatient to see what others think, they reflect on feedback and spontaneously refine and defend what they have been trying to say. They grow in maturity, aware that others find their ideas and opinions worthy of serious consideration.

Fredig (2004) maintains that language facilitates social interactions and that the process of commenting and responding to blogs helps scaffold the meanings attached to phenomena. However, due to the relative infancy of using blogging in schools, there have been few systematic studies of the instructional potential of its impact. In Singapore, Sim (2008) explored the use of blogging in schools in the belief that the cycle of posting and commenting between group members is a route to secure learning. Sim suggests an interactive blogging model consisting of four levels. At levels one and two, the bulk of entries feature one-way entries. At the third level there are two-way exchanges of short duration, and at the fourth stage there is diverse flow of information and ideas.

The exploratory work of Sim (2008) and others inspired the writers to investigate the potential impact of blogging on students in Hong Kong, where it is hoped that school leavers will be bilingual in Chinese and English. In fact, the learning of English, an alphabetic language, and Chinese, an idiographic language, is a complicated affair for students. The syntax and semantics of English and Chinese are dissimilar and this 
often confuses learners. The researchers thus set out to examine the relative ability of primary school students in Hong Kong to comprehend text in Chinese, the mother tongue, and in English, the second language. They also investigated the potential of Internet activities for developing reading literacy in both languages in the primary school.

The research team was involved in the "Progress in Reading Literacy Study" (PIRLS) in both the 2001 and 2006 cycles, an investigation looking at the reading standards of students and factors affecting reading in 35 to 45 countries/regions worldwide (Campbell, Kelly, Mullis, Martin \& Sainsbury, 2001; Mullis, Kennedy, Martin \& Sainsbury, 2006). The PIRLS survey defines reading literacy as:

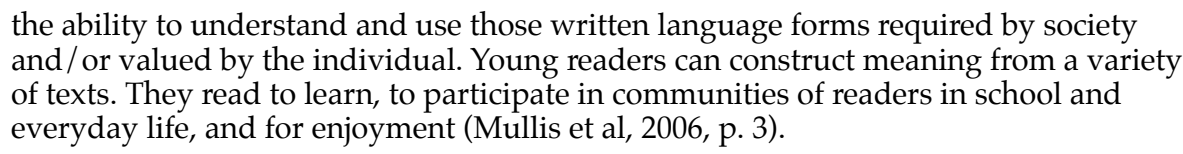

The principal investigator had been responsible for directing the Hong Kong element of the PIRLS survey and, in 2007, initiated a study specifically examining the bilingual reading literacy of Primary 4 students in Hong Kong. Aware that blogging was becoming increasingly popular among primary school students, the Hong Kong team modified the PIRLS research framework and instrumentation and looked at the impact of Chinese and English blogging activities on Grade Four students' Chinese and English reading attainment.

\section{Research objectives}

The study set out to discover the extent to which Hong Kong Grade 4 students consulted the Internet or engaged in blogging activities. With those students who said they did, the team set out to ascertain the proportion that looked at Chinese sites and at English sites. Would there be a difference between boys and girls in the incidence of looking at the internet and the type of sites consulted, and was there any significant association between reading attainment and engagement in blogging activities on Chinese versus English sites?

\section{Method}

\section{Sample}

The participants in this study consisted of 1,298 Grade Four students, mostly about nine or ten years old, chosen using procedures recommended by the International Association for the Evaluation of Educational Achievement (IEA) (Mullis, Martin, Gonzalez \& Kennedy, 2003). Forty schools were selected randomly and two classes chosen randomly from each school to represent the Hong Kong sample in May 2007.

\section{Measurement instruments}

Two measuring instruments were used. One was a questionnaire gathering demographic information about the students and asking, among other things, whether they had experience of Internet and blogging activities in Chinese and English. The other took the form of standardised reading tests consisting of two broad elements: "reading for literary experience" and "reading to acquire and use information". The 
tests were based on texts used in the PIRLS survey organised by the IEA, meticulously constructed to produce norms enabling comparisons between students in different countries or regions. The attainment tests are based on a sophisticated model of reading comprehension and assessed children's comprehension skills and reading strategies (Tse, Lam, Lam \& Loh, 2003; 2006).

The PIRLS surveys assess students' reading by sampling performance over a variety of text types: four concerned with reading for information and four of a narrative nature. The comprehension passages used in the present study were the English standard version of the PIRLS materials used in all participating countries or regions, and a Chinese version specially translated by the team for the Hong Kong element of testing. The passages were subjected to independent scrutiny to establish equivalence, and content was verified by language experts to ensure that both the English and Chinese versions of the test had the same level of difficulty and equivalent semantic characteristics. This permitted students' English and Chinese reading performance to be compared validly.

\section{Results}

Background information about the students is summarised in Table 1, where it can be seen that, of the 1,298 Grade 4 students, two in five said they had read Chinese blogs and about one in five that they had browsed English blogs.

Table 1: Background of respondents $(\mathrm{N}=1298)$

\begin{tabular}{|c|c|c|c|}
\hline & & & $\%$ \\
\hline Gende & & Male & 49.8 \\
\hline & & Female & 50.2 \\
\hline Age (y & & $<9$ & 1.6 \\
\hline & & $9-10$ & 96.0 \\
\hline & & $>10$ & 2.4 \\
\hline Have & ktop or laptop & Yes & 62.5 \\
\hline & & No & 37.5 \\
\hline Read & Chinese blogs & Yes & 41.5 \\
\hline blogs & & No & 58.5 \\
\hline & English blogs & Yes & 18.6 \\
\hline & & No & 81.4 \\
\hline
\end{tabular}

\section{Factor analysis}

The relationships between demographic variables and attainment scores were correlated and the matrices subjected to factor analysis. Table 2 shows that the factor loadings of individual items relating to Chinese blogging activities ranged from 0.66 to 0.88. The percentage of variance explained by the factors ranged from 18.51 to 33.6, and the Eigen values ranged from 1.85 to 3.36. The English blogging behaviour factor analysis summarised in Table 2 show factor loadings of items ranging from 0.61 to 0.90. The percentage of variance explained by those two factors is 44.05 and 29.77 respectively, with Eigen values of 2.98 to 4.40 (see Table 2). 
Table 2: Factor analysis - Chinese and English blogging

\begin{tabular}{|c|c|c|c|}
\hline \multirow{2}{*}{ Chinese blogging item(s) } & \multicolumn{3}{|c|}{ Components } \\
\hline & 1 & 2 & 3 \\
\hline Browse student's own blog & 0.79 & 0.12 & 0.08 \\
\hline Browse friends and classmates' blogs & 0.77 & 0.26 & 0.10 \\
\hline Browse net friends' blogs & 0.69 & 0.15 & 0.41 \\
\hline Response to friends and classmates' blogs & 0.75 & 0.35 & 0.12 \\
\hline Response to net friends' blogs & 0.66 & 0.21 & 0.46 \\
\hline Compose Chinese blog & 0.71 & 0.07 & 0.12 \\
\hline Browse famous stars and celebrities' blogs & 0.23 & 0.88 & 0.15 \\
\hline Response to famous stars and celebrities' blogs & 0.24 & 0.85 & 0.24 \\
\hline Browse blogs of unknown people & 0.17 & 0.11 & 0.88 \\
\hline Response to blogs of unknown people & 0.16 & 0.25 & 0.88 \\
\hline Eigen values & 3.36 & 1.851 & 2.053 \\
\hline Variance explained (\%) & 33.60 & 18.51 & 20.53 \\
\hline \multirow{2}{*}{ English blogging item(s) } & \multicolumn{3}{|c|}{ Components } \\
\hline & 1 & & 2 \\
\hline Reading student's own blog & 0.85 & & 0.24 \\
\hline Reading friends and classmates' blogs & 0.79 & & 0.34 \\
\hline Reading net friends' blogs & 0.77 & & 0.41 \\
\hline Responding to friends and classmates' blogs & 0.84 & & 0.28 \\
\hline Responding to net friends' blogs & 0.75 & & 0.43 \\
\hline Writing their own English blog & 0.70 & & 0.17 \\
\hline Reading famous stars and celebrities' blogs & 0.53 & & 0.61 \\
\hline Reading blogs of unknown people & 0.22 & & 0.88 \\
\hline Responding to famous stars and celebrities' blogs & 0.55 & & 0.63 \\
\hline Responding to blogs of unknown people & 0.26 & & 0.90 \\
\hline Eigen values & 4.40 & & 2.98 \\
\hline Variance explained (\%) & 44.05 & & 29.77 \\
\hline
\end{tabular}

\section{Between group differences and analysis of variance}

In order to examine differences in the relative attention paid to Chinese and English blogs, analysis of variance was applied to the reported strengths of access to Chinese and English blogs alongside mean reading scores ("personal and friends" $x$ Chinese reading literacy mean score; "stars and celebrities" x Chinese reading literacy mean score; "unknown people" x Chinese reading literacy mean score). For Chinese blogging behaviour, the "personal and friends" construct had a significant effect on the Chinese reading literacy attainment scores of the students, $F(2,335)=4.88$, p < 0.05. The "stars and celebrities" construct also had a significant effect on Chinese reading literacy, $F(2,335)=6.927, \mathrm{p}<0.01$. The "unknown people" construct had no significant effect on Chinese reading attainment. In terms of English reading literacy, the two constructs had no significant effect.

A descriptive summary of reading performance and background variables is presented in Table 3, together with Cronbach's alpha coefficient indices of the internal consistency of key variables. Chinese blogging behaviour responses attracted alpha coefficients ranging from 0.83 to 0.87 , and English blogging behaviour responses attracted alpha coefficients ranging from 0.89 to 0.92 . In other words, the data seem very reliable in terms of internal consistency. 
Table 3: Descriptive analysis - Chinese and English blogging activities

\begin{tabular}{|c|c|c|c|c|c|c|c|}
\hline \multirow{2}{*}{\multicolumn{2}{|c|}{ Item(s) }} & \multirow[t]{2}{*}{$\mathrm{N}$} & \multirow[t]{2}{*}{ Min. } & \multirow[t]{2}{*}{ Max. } & \multicolumn{2}{|c|}{$\begin{array}{c}\text { Frequency of } \\
\text { blogging } \\
\text { behaviours }\end{array}$} & \multirow[t]{2}{*}{ Alpha } \\
\hline & & & & & Mean & SD & \\
\hline \multirow{10}{*}{$\begin{array}{l}\text { Chinese } \\
\text { blogging } \\
\text { behaviours }\end{array}$} & Browse student's own blog & 635 & 1 & 4 & 2.42 & 1.26 & \multirow[t]{6}{*}{0.873} \\
\hline & Browse friends and classmates' blogs & 636 & 1 & 4 & 2.38 & 1.17 & \\
\hline & Browse net friends' blogs & 635 & 1 & 4 & 2.18 & 1.22 & \\
\hline & $\begin{array}{l}\text { Response to friends and classmates' } \\
\text { blogs }\end{array}$ & 430 & 1 & 4 & 2.49 & 1.15 & \\
\hline & Response to net friends' blogs & 429 & 1 & 4 & 2.32 & 1.21 & \\
\hline & Compose Chinese blog & 1130 & 1 & 4 & 1.84 & 1.12 & \\
\hline & $\begin{array}{l}\text { Browse famous stars and celebrities' } \\
\text { blogs }\end{array}$ & 638 & 1 & 4 & 2.26 & 1.12 & \multirow[t]{2}{*}{0.834} \\
\hline & $\begin{array}{l}\begin{array}{l}\text { Response to famous stars and } \\
\text { celebrities' blogs }\end{array} \\
\end{array}$ & 431 & 1 & 4 & 2.16 & 1.14 & \\
\hline & Browse blogs of unknown people & 634 & 1 & 4 & 1.58 & 0.99 & \multirow[t]{2}{*}{0.852} \\
\hline & Response to blogs of unknown people & 423 & 1 & 4 & 1.74 & 1.10 & \\
\hline \multirow{10}{*}{\begin{tabular}{|l} 
English \\
blogging \\
behaviours
\end{tabular}} & Browse student's own blog & 318 & 1 & 4 & 2.18 & 1.22 & \multirow[t]{6}{*}{0.92} \\
\hline & Browse friends and classmates' blogs & 318 & 1 & 4 & 2.15 & 1.15 & \\
\hline & Browse Net friends' blogs & 319 & 1 & 4 & 2.01 & 1.16 & \\
\hline & Response friends and classmates' blogs & 283 & 1 & 4 & 2.30 & 1.18 & \\
\hline & Response Net friends' blogs & 281 & 1 & 4 & 2.15 & 1.19 & \\
\hline & Compose English blog & 1198 & 1 & 4 & 1.20 & 0.40 & \\
\hline & $\begin{array}{l}\text { Browse famous stars and celebrities' } \\
\text { blogs }\end{array}$ & 323 & 1 & 4 & 2.14 & 1.16 & \multirow[t]{4}{*}{0.89} \\
\hline & Browse blogs of unknown people & 323 & 1 & 4 & 1.67 & 1.04 & \\
\hline & $\begin{array}{l}\text { Response to famous stars and } \\
\text { celebrities' blogs }\end{array}$ & 283 & 1 & 4 & 2.10 & 1.19 & \\
\hline & Response to blogs of unknown people & 280 & 1 & 4 & 1.75 & 1.09 & \\
\hline
\end{tabular}

\section{The relationship between students' Chinese and English blogging behaviour and reading scores}

Correlational analysis of students reading ability and engagement in any particular type of language blog is not robust, as not all of the children surveyed said they consulted websites. In the event, a negative correlation was found between the students Chinese reading performance and access to the "stars and celebrities" web site $(r=-0.156, \mathrm{p}<0.01)$, access to the "personal and friends" web site $(r=-0.127, \mathrm{p}<$ $0.05)$ and access to the "unknown people" web site $(r=-0.118, \mathrm{p}<0.05)$. In order to permit post hoc analysis of the relationship between reading level and degree of the engagement in certain web constructs, the researchers divided students into three groups "High", "Medium" and "Low" in terms of frequency of blogging activity over certain constructs. "High" frequency of blogging activity applied to students who said they participated in blogging ranging from 2.01 - 3.0 (from "everyday or almost everyday" to "once or twice per week"); "Medium" frequency applied to groups who said they blogged from 1.01 - 2.0 (from "once or twice per month" to "once or twice per week"); and a "Low" group who said they blogged from 0 to 1.0 (from "never or almost never" to "once or twice per month"). Looking at differences in mean scores, it 
was found that, for the "personal and friends" construct, the mean difference of the "Medium" group was higher than "High" and "Low" groups with 27.36, p $<0.05$ and $14.52, \mathrm{p}<0.05$ respectively. This seems to indicate that students who engage in "personal and friends" construct at a medium level, achieved better Chinese reading literacy scores than the students in the "High" and "Low" groups.

For the "stars and celebrities" construct, the mean differences both of "Medium" and "Low" groups were higher than for the "High" group, with $28.85(\mathrm{p}<0.05)$ and 27.46 $(p<0.05)$ respectively. The results suggest that students who regularly engage in blogging activities about "stars and celebrities" had Chinese reading performance that was negatively affected.

\section{Blogging, reading performance and gender}

Separate factor analyses were carried out for boys and girls in terms of the types of the blogging behaviour they said they had engaged in. Three factors or constructs emerged: (a) reading, writing and responding to personal, friends' and classmates' Chinese blogs, (b) reading and responding to Chinese blogs of famous people and pop stars blogs, (c) and reading and responding to Chinese blogs about unfamiliar people (see Table 4). The factor loadings of girls ranged from 0.611 to $0.827,0.856$ and 0.879 , and 0.812 and 0.869 respectively (Table 4 ). The factor loadings of boys ranged from 0.625 to $0.797,0.864$ and 0.865 , and 0.874 and 0.893 (see Table 4 ). The girls' and boys' Chinese blogging behavioural patterns are similar, suggesting that boys and girls at this age share similar interests and they respond to blogs with similar enthusiasm: personal friends' blogs, classmates' blogs then strangers' blogs.

Table 4: Factor analysis of girls' and boys' blogging behaviours of Chinese blogs

\begin{tabular}{|c|c|c|c|c|}
\hline & \multirow{2}{*}{ Factor(s) (a) } & \multicolumn{3}{|c|}{ Component } \\
\hline & & 1 & 2 & 3 \\
\hline \multirow{10}{*}{$\begin{array}{l}\text { Girls' } \\
\text { Chinese } \\
\text { blogging } \\
\text { behaviours }\end{array}$} & Reading Chinese blogs: friends' or classmates' blogs & .827 & & \\
\hline & Responding to Chinese blogs: friends' or classmates' blogs & .826 & & \\
\hline & Reading Chinese blog: your own blog & .757 & & \\
\hline & Reading Chinese blog: close net friends' blogs & .693 & .476 & \\
\hline & Responding to Chinese blogs: close net friends' blogs & 650 & .558 & \\
\hline & Write your own Chinese blog & .611 & & \\
\hline & Reading Chinese blog: unfamiliar people's blogs & & .879 & \\
\hline & Responding to Chinese blogs: unfamiliar people's blogs & & .856 & \\
\hline & Reading Chinese blog: famous people's or pop stars' blogs & & & .869 \\
\hline & Responding to Chinese blogs: famous people's or pop stars' blogs & & & .812 \\
\hline \multirow{10}{*}{$\begin{array}{l}\text { Boys' } \\
\text { Chinese } \\
\text { blogging } \\
\text { behaviours }\end{array}$} & Write your own Chinese blog & .797 & & \\
\hline & Reading Chinese blog: your own blog & .795 & & \\
\hline & Reading Chinese blogs: close net friends' blogs & 695 & & \\
\hline & Reading Chinese blogs: friends' or classmates' blogs & 686 & & \\
\hline & Responding to Chinese blogs: close net friends' blogs & 659 & .423 & \\
\hline & Responding to Chinese blogs: friends' or classmates' blogs & .626 & .545 & \\
\hline & Responding to Chinese blogs: famous people's or pop stars' blogs & & .865 & \\
\hline & Reading Chinese blog: famous people's or pop stars' blogs & & .864 & \\
\hline & Reading Chinese blog: unfamiliar people's blogs & & & .893 \\
\hline & Responding to Chinese blogs: unfamiliar people's blogs & & & .874 \\
\hline
\end{tabular}


In the case of English blogs, the behavioural patterns of girls and boys differed. Two constructs of girls' English blogging behaviour could be identified: (a) reading, writing and responding to personal, friends' and classmates' English blogs (factor loading ranging from 0.741 to 0.827 ) (see Table 5), and (b) reading and responding to Chinese blogs of famous people, pop stars, and unfamiliar people (factor loading ranging from 0.698 to 0.870 ) (see Table 5). Only one factor of boys' English blogging behaviour emerged (see Table 5).

Table 5: Factor analysis of blogging behaviour involving English blogs

\begin{tabular}{|c|c|c|c|}
\hline & \multirow{2}{*}{ Factor(s) } & \multicolumn{2}{|c|}{ Component } \\
\hline & & 1 & 2 \\
\hline \multirow{10}{*}{$\begin{array}{l}\text { Girls' English } \\
\text { blogging } \\
\text { behaviours (a) }\end{array}$} & Responding to English blogs: friends' or classmates' blogs & .827 & \\
\hline & Reading English blog: your own blog & .823 & \\
\hline & Reading English blogs: friends' or classmates' blogs & .818 & \\
\hline & Reading to English blogs: close Net friends' blogs & .770 & .421 \\
\hline & Write your own English blog & .742 & \\
\hline & Responding to English blogs: close Net friends' blogs & .741 & .471 \\
\hline & Responding to English blogs: unfamiliar people's blogs & & .870 \\
\hline & Reading English blog: unfamiliar people's blogs & & .818 \\
\hline & Responding to English blogs: famous people's or pop stars' blogs & & .746 \\
\hline & Reading English blog: famous people's or pop stars' blogs & & .698 \\
\hline \multicolumn{4}{|c|}{$\begin{array}{l}\text { Extraction method: Principal component analysis. } \\
\text { Rotation method: Varimax with Kaiser normalisation. } \\
\text { a. Rotation converged in } 3 \text { iterations. }\end{array}$} \\
\hline \multirow{10}{*}{$\begin{array}{l}\text { Boys' English } \\
\text { blogging } \\
\text { behaviours } \\
\text { (b) }\end{array}$} & Responding to English blogs: famous people's or pop stars' blogs & .869 & \\
\hline & Responding to English blogs: friends' or classmates' blogs & .861 & \\
\hline & Reading to English blogs: close net friends' blogs & .857 & \\
\hline & Reading English blogs: friends' or classmates' blogs & .854 & \\
\hline & Reading English blog: your own blog & .853 & \\
\hline & Reading English blog: famous people's or pop stars' blogs & .852 & \\
\hline & Responding to English blogs: close net friends' blogs & .848 & \\
\hline & Responding to English blogs: unfamiliar people's blogs & .762 & \\
\hline & Reading English blog: unfamiliar people's blogs & .700 & \\
\hline & Write your own English blog & .617 & \\
\hline
\end{tabular}

The impact of Chinese and English blogging behaviour on girls' and boys' Chinese reading attainment was investigated and ANOVA was applied. It was found that girls with "Medium" level of blogging of "personal, friends, and classmates Chinese blogs", "unfamiliar people's Chinese blogs", and "famous people's and pop stars' blogs" had superior Chinese reading attainment scores than their girl counterparts $(\mathrm{M}=582.61$, 572.66 and 582.23 respectively) (see Table 6). As for the impact of Chinese blogging behaviour on boys' Chinese reading attainment, those with "Medium" level of the blogging of "personal, friends' and classmates' blogs", but "Low" level of blogging of "unfamiliar people's blogs" and "famous people's and pop stars' blogs" had the highest level of Chinese reading attainment $(\mathrm{M}=558.57,551.93$, and 562.11 respectively).

There were statistically significant gender differences in the "famous people's and pop stars' blogs" construct of Chinese blogging behaviours (Eta ${ }^{2}$ ranging from 0.034 to 0.049) (see Table 6). The gender difference in reading score is least for the group of "Low" level of the blogging of Chinese "famous people's and pop stars' blogs", 
compared to the other two constructs. A t-test was conducted to compare the difference between boys' and girls' consulting of Chinese "famous people's and pop stars' blogs". On average, girls had a higher frequency in consulting Chinese "famous people's and pop stars' blogs" $(\mathrm{M}=2.17, \mathrm{SD}=0.76)$ than boys $(\mathrm{M}=2.00, \mathrm{SD}=0.853)$. This difference was marginally statistically significant, $t(401)=2.103, \mathrm{p}<.05$, indicating that girls tended to be more frequently involved in Chinese blogs relating to "famous people and pop stars" than boys.

Table 6: Analyses of gender differences on Chinese blogging behaviour

\begin{tabular}{|c|c|c|c|c|c|c|c|}
\hline \multirow{7}{*}{$\begin{array}{l}\text { Chinese blog: } \\
\text { Personal, friends' } \\
\text { and classmates' } \\
\text { blogs }\end{array}$} & Gender & Frequency & $\mathrm{N}$ & Reading score & SD & $F$ & $\mathrm{Eta}^{2}$ \\
\hline & \multirow[t]{3}{*}{ Girls } & Low & 28 & 571.58 & 74.131 & \multirow[t]{3}{*}{1.850} & \multirow[t]{3}{*}{.021} \\
\hline & & Medium & 64 & 582.61 & 57.574 & & \\
\hline & & High & 80 & 560.89 & 72.026 & & \\
\hline & \multirow[t]{3}{*}{ Boys } & Low & 22 & 539.31 & 83.451 & \multirow[t]{3}{*}{$3.554^{*}$} & \multirow[t]{3}{*}{.042} \\
\hline & & Medium & 68 & 558.57 & 76.049 & & \\
\hline & & High & 76 & 523.89 & 78.028 & & \\
\hline \multirow{6}{*}{$\begin{array}{l}\text { Chinese blog: } \\
\text { Unfamiliar } \\
\text { people's blogs }\end{array}$} & \multirow[t]{3}{*}{ Girls } & Low & 120 & 570.95 & 62.052 & \multirow[t]{3}{*}{.692} & \multirow[t]{3}{*}{.007} \\
\hline & & Medium & 49 & 572.66 & 79.827 & & \\
\hline & & High & 33 & 555.96 & 79.521 & & \\
\hline & \multirow[t]{3}{*}{ Boys } & Low & 99 & 551.93 & 78.928 & \multirow[t]{3}{*}{1.550} & \multirow[t]{3}{*}{.016} \\
\hline & & Medium & 53 & 530.79 & 69.396 & & \\
\hline & & High & 36 & 534.33 & 82.975 & & \\
\hline \multirow{6}{*}{$\begin{array}{l}\text { Chinese blog: } \\
\text { Famous people's } \\
\text { and pop stars' } \\
\text { blogs }\end{array}$} & Girls & Low & 44 & 573.73 & 69.870 & \multirow[t]{3}{*}{$3.503^{*}$} & \multirow[t]{3}{*}{.034} \\
\hline & & Medium & 81 & 582.23 & 56.435 & & \\
\hline & & High & 79 & 553.96 & 78.558 & & \\
\hline & \multirow[t]{3}{*}{ Boys } & Low & 71 & 562.11 & 69.493 & \multirow[t]{3}{*}{$4.892^{\star *}$} & \multirow[t]{3}{*}{.049} \\
\hline & & Medium & 51 & 545.26 & 73.430 & & \\
\hline & & High & 71 & 522.55 & 82.591 & & \\
\hline \multicolumn{8}{|c|}{$\begin{array}{l}\text { Notes: } \\
\text { Girls' Chinese blogging: Personal, friends' and classmates' blogs }(F(2,169)=1.850, \mathrm{p}=0.160) \\
\text { Girls' Chinese blogging: Unfamiliar people's blogs }(F(2,199)=0.692, \mathrm{p}=.502) \\
\text { Girls' Chinese blogging: Famous people's and pop stars' blogs }\left(F(2,201)=3.503^{*}, \mathrm{p}<0.05\right) \\
\text { Boys' Chinese blogging: Personal, friends' and classmates' blogs }\left(F(2,163)=3.554^{*}, \mathrm{p}<0.05\right) \\
\text { Boys' Chinese blogging: Unfamiliar people's blogs }(F(2,185)=1.550, \mathrm{p}=.215) \\
\text { Boys' Chinese blogging: Famous people's and pop stars' blogs }\left(F(2,190)=4.892^{*}, \mathrm{p}<0.01\right)\end{array}$} \\
\hline
\end{tabular}

Turning to the analyses of gender differences in English blogging behaviour, it was found that girls with a "Medium" level of writing, reading and responding to "personal, friends and classmates" and "famous people's, pop stars and unfamiliar people's" English blogs had superior English reading attainment over that of their girl counterparts (see Table 7). The impact of English blogging behaviour was different for boys. Those with a "High" level of writing, reading and responding to "personal, friends and classmates" English blogs and a "Medium" level of reading and responding to "famous people's, pop stars' and unfamiliar people's" English blogs performed better on the English reading test than did their boy counterparts. However, the gender differences on the two constructs of students' English blogging were insignificant (Eta ${ }^{2}$ were 0.001 to 0.451 respectively) (see Table 7).

\section{Gender and students' Chinese and English blogging behaviour}

Correlational analysis revealed a positive and significant correlation between girls' Chinese blogging behaviour types ( $\mathrm{r}$ ranging from $0.50^{* * *}$ to $0.52^{* * *}$ ). There was a negative but significant relationship between their Chinese reading attainment scores 
and their blogging of "famous people's and pop stars"" Chinese blogs $\left(\mathrm{r}=-0.16^{*}\right)$. Although there were negative impacts of blogging of their own Chinese blogs and "friends', classmates' and unfamiliar people's" Chinese blogs on their Chinese reading achievement, the impacts were non-statistically significant (see Table 8).

Table 7: Analyses of gender differences on English blogging behaviour

\begin{tabular}{|c|c|c|c|c|c|c|c|}
\hline & Gender & Frequency & $\mathrm{N}$ & Reading score & SD & $\mathrm{F}$ & $\mathrm{Eta}^{2}$ \\
\hline \multirow{6}{*}{$\begin{array}{l}\text { English blog: } \\
\text { Personal, friends' } \\
\text { and classmates' } \\
\text { blogs }\end{array}$} & \multirow[t]{3}{*}{ Girls } & Low & 33 & 387.00 & 87.44 & \multirow{3}{*}{1.297} & \multirow{3}{*}{.027} \\
\hline & & Medium & 30 & 421.56 & 94.34 & & \\
\hline & & High & 34 & 411.05 & 82.36 & & \\
\hline & \multirow[t]{3}{*}{ Boys } & Low & 33 & 383.72 & 82.31 & \multirow[t]{3}{*}{.803} & \multirow[t]{3}{*}{.451} \\
\hline & & Medium & 34 & 403.71 & 87.65 & & \\
\hline & & High & 42 & 410.05 & 100.92 & & \\
\hline \multirow{6}{*}{$\begin{array}{l}\text { English blog: } \\
\text { Famous people's, } \\
\text { pop stars', and } \\
\text { unfamiliar } \\
\text { people's blogs }\end{array}$} & \multirow[t]{3}{*}{ Girls } & Low & 59 & 414.77 & 90.06 & \multirow[t]{3}{*}{.571} & \multirow[t]{3}{*}{.009} \\
\hline & & Medium & 42 & 422.82 & 90.76 & & \\
\hline & & High & 28 & 399.38 & 89.54 & & \\
\hline & \multirow[t]{3}{*}{ Boys } & Low & 52 & 399.09 & 90.45 & \multirow[t]{3}{*}{.043} & \multirow[t]{3}{*}{.001} \\
\hline & & Medium & 37 & 404.22 & 86.73 & & \\
\hline & & High & 37 & 403.79 & 100.36 & & \\
\hline \multicolumn{8}{|c|}{$\begin{array}{l}\text { Notes: } \\
\text { Girls' English blogging: Personal, friends' and classmates' blogs }(F(2,94)=1.297, \mathrm{p}=.0278) \\
\text { Boys' English blogging: Personal, friends' and classmates' blogs }(F(2,106)=0.803, \mathrm{p}=0.451) \\
\text { Girls' English blogging: Famous people's, pop stars', and unfamiliar people's blogs }(F(2,126)= \\
0.571, \mathrm{p}=0.567) \\
\text { Boys' English blogging: Famous people's, pop stars', and unfamiliar people's blogs }(F(2,123)= \\
0.043, \mathrm{p}=0.958)\end{array}$} \\
\hline
\end{tabular}

Table 8: Correlations between girls' and boys' Chinese blogging behaviour and Chinese reading attainment

\begin{tabular}{|c|c|c|c|c|c|}
\hline & Item(s) & 1. & 2. & 3. & 4. \\
\hline \multirow{4}{*}{$\begin{array}{l}\text { Girls' Chinese } \\
\text { blogging } \\
\text { behaviours }\end{array}$} & 1. Chinese reading scores & 1.00 & & & \\
\hline & $\begin{array}{l}\text { 2. Chinese blog: Personal, friends' and } \\
\text { classmates' blogs }\end{array}$ & -0.09 & 1.00 & & \\
\hline & 3. Chinese blog: Unfamiliar people's blogs & -0.09 & $0.52^{* * *}$ & 1.00 & \\
\hline & $\begin{array}{l}\text { 4. Chinese blog: Famous people's and pop } \\
\text { stars' blogs }\end{array}$ & $-0.16^{*}$ & $0.50^{* * *}$ & $0.50^{* * *}$ & 1.00 \\
\hline \multirow{4}{*}{$\begin{array}{l}\text { Boys' Chinese } \\
\text { blogging } \\
\text { behaviours }\end{array}$} & 1. Chinese reading scores & 1.00 & & & \\
\hline & $\begin{array}{l}\text { 2. Chinese blog: Personal, friends' and } \\
\text { classmates' blogs }\end{array}$ & $-0.17^{*}$ & 1.00 & & \\
\hline & 3. Chinese blog: Unfamiliar people's blogs & -0.13 & $0.44^{* * *}$ & 1.00 & \\
\hline & $\begin{array}{l}\text { 4. Chinese blog: Famous people's and pop } \\
\text { stars' blogs }\end{array}$ & $-0.26^{* * *}$ & $0.54^{* * \star}$ & $0.42^{* * *}$ & 1.00 \\
\hline
\end{tabular}

Correlational analysis revealed a positive and significant correlation between girls' types of English blogging behaviour and reading scores $\left(\mathrm{r}=0.68^{* * *}\right)$. There was a positive impact of blogging of "personal, friends', classmates' and unfamiliar people's" on English reading attainment. There was a non-statistically significant impact of blogging involving "famous people's, pop stars' and unfamiliar people's" English blogs on English reading achievement (see Table 9).

Correlation analysis revealed a positively significant correlation between boys' types of English blogging behaviour $\left(r=0.78^{\star * *}\right)$. There was a positive impact for blogging 
involving "personal, friends', classmates' and unfamiliar people's" and "famous people's, pop stars' and unfamiliar people's" on their English reading attainment but the impact of both was non-significant (see Table 9).

Table 9: Correlation between girls' and boys' English blogging behaviour and English reading attainment

\begin{tabular}{|c|c|c|c|c|}
\hline & $\operatorname{Item}(\mathrm{s})$ & 1. & 2. & 3. \\
\hline \multirow{3}{*}{$\begin{array}{l}\text { Girls' English } \\
\text { blogging } \\
\text { behaviours }\end{array}$} & 1. English reading scores & 1.00 & & \\
\hline & 2. English blog: Personal, friends' and classmates' blogs & 0.06 & 1.00 & \\
\hline & \begin{tabular}{l|l} 
3. & $\begin{array}{l}\text { English blog: Famous people's, pop stars' and } \\
\text { unfamiliar people's blogs }\end{array}$
\end{tabular} & -0.01 & $0.68^{* *}$ & 1.00 \\
\hline \multirow{3}{*}{$\begin{array}{l}\text { Boys' English } \\
\text { blogging } \\
\text { behaviours }\end{array}$} & 1. English reading scores & 1.00 & & \\
\hline & 2. English blog: Personal, friends' and classmates' blogs & 0.12 & 1.00 & \\
\hline & $\begin{array}{l}\text { 3. } \begin{array}{l}\text { English blog: Famous people's, pop stars' and } \\
\text { unfamiliar people's blogs }\end{array} \\
\text { and }\end{array}$ & 0.004 & $0.78^{\star * \star}$ & 1.00 \\
\hline
\end{tabular}

\section{Discussion and conclusion}

Looking first at the pattern of blogging behaviour engaged in by Hong Kong Grade 4 students, the proportion of students reading Chinese blogs is double that of students reading English blogs. This is not surprising since Chinese is the first language of most Grade 4 students in Hong Kong and English is only the second. At the same time, Chinese blogs are much more accessible than English blogs for students. Few primary school students have sufficiently high English reading proficiency to cope with and comprehend advanced English blogs. Song and Chan (2008) report a similar finding with Malaysian students, and they conclude that students' poor English competency lowers their readiness to participate. However, since blogging is a fairly recent and novel activity and since many English sites are very attractive, the researchers would expect to see more and more students consulting English blogs in the privacy of their own homes.

It was found in the clustering of types of Chinese blogs consulted that three categories emerged: "personal and friends", "stars and celebrities" and "unknown people". Only two of these categories were unambiguously present in the range of English blogging activities: "personal and friends" and "stars and people unknown" based on the above factor analysis. The researchers gained the impression that these categories relate to the "social distance" of students and to their language proficiency (see Figure 1).

Boys and girls differed in their choice of Chinese and English blogging topics, and the students' Chinese and strength of English reading proficiency clearly had some influence on the size and choice of websites consulted. Blogging as a pastime activity is relatively new in Hong Kong and, as yet, is not an activity on the primary school timetable. Nor is it widely regarded as an activity that has potential for boosting students' language skills and self confidence as readers, as advocated by BartlettBragg (2003) and Sim (2008). Many teachers of Chinese and English feel stressed with their teaching load and will resist the incorporation of blogging activities into the fairly small amount of time allocated for teaching English and Chinese. However, teachers are pragmatic and they are becoming increasingly sensitive to the potential of blog activity for boosting learning: indeed Chen and Zhang (2003) report that blogging has a noticeable positive effect in the classroom if persistence is encouraged. There are 
teething problems however, and Hong Kong teachers, like their counterparts in other countries (Song \& Chan, 2008), are encountering logging in and other technical difficulties. It has first to be faced that many Hong Kong primary teachers are nervous about teaching lessons involving hands on information technology. Perhaps they too can benefit from working together in clusters to hone their Chinese and English language prowess.

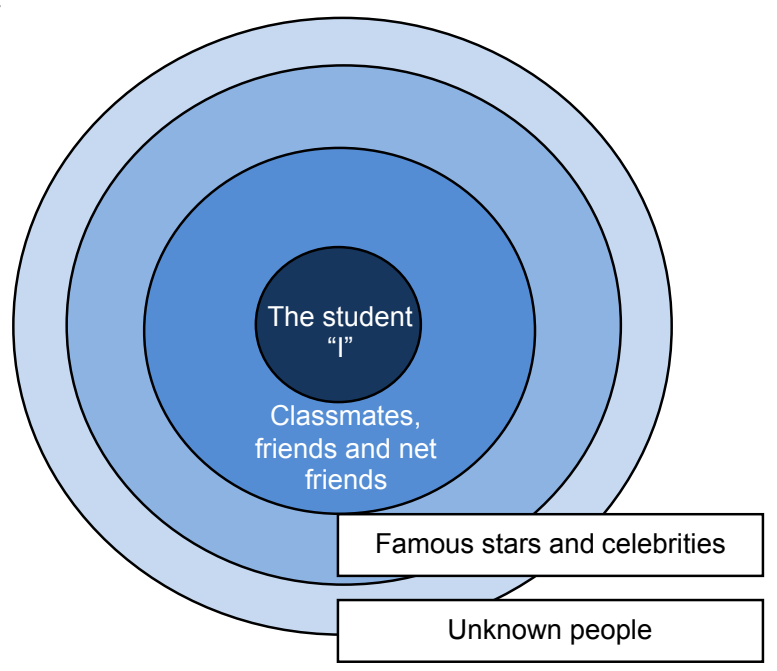

Chinese blogging

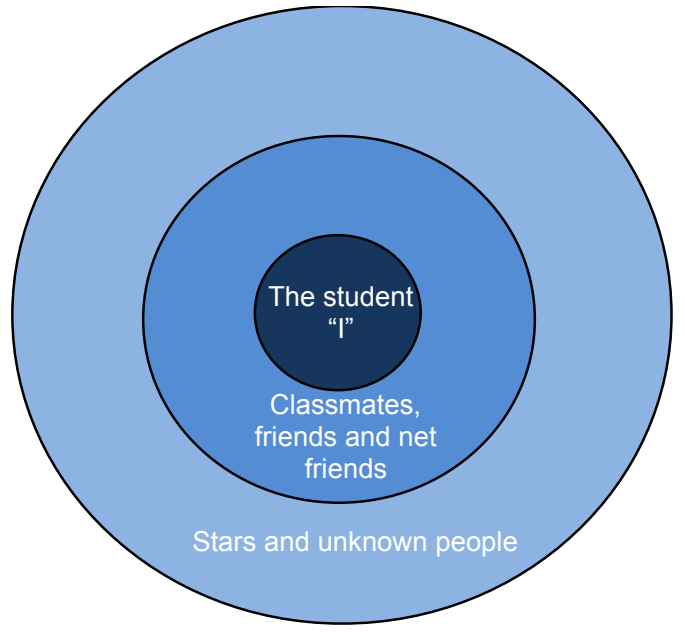

English blogging

Figure 1: Clustering of types of Chinese and English blogs Chinese students consulted

Although it is speculative on the outcomes of the present research to pronounce on the value of blogging as an activity with educational potential, there is evidence of likely benefits. Left entirely to their own devices, the students surveyed said they looked at 
Chinese blogs about famous people and pop stars, and personal friends' and classmates' Chinese blogs. Four out of five students gave responses hinting that they lacked the confidence and English language proficiency to tackle blogs and web sites in English. This gives food for thought, as the evidence cited earlier suggests that students' second language competence will benefit considerably from contributing and writing English blogs. Although it is probably too early at present to detect the impact of blogging on Hong Kong students' literacy, the situation needs to be monitored and surveys need to be conducted in the near future. In terms of the present study, it would be quite speculative to talk about the $80 \%$ of students who said they had never consulted a website in English or an English language blog. Likewise it is unwise to comment on the $60 \%$ of students who had never visited Chinese language web sites.

On the other hand, there is firm evidence that, without any prompting whatever from their school, many Hong Kong students are actually looking at blogs and websites both in Chinese and in English. Educators and schools should capitalise on this and perhaps encourage students to write their own blogs and contribute to the blogs of others. Teachers should not dismiss the findings of the present research on the grounds that its authors advise caution. Conhaim (2002) reports that blogging is an activity that students are turning to whether or not it is encouraged in school. This will help develop confidence in their ability to learn outside the classroom, and lead students to consult Chinese and English blogs. It is important to note that students in the present study who had taken the initiative to respond to English blogs were displaying superior English reading performance. Success breeds success and one would expect this to encourage further effort. These students may also serve as role models for their peers.

Due to the fact that blogging is in its infancy, websites separately catering for boys and girls are thin on the ground at the moment. The present study found that boys and girls have similar interests in Chinese blog topics but have different preferences in reading and responding to English blogs. Gender differences in blogging interests and behavioural patterns are in line with existing findings that girls are more interested in topics relating to interpersonal relationship and societal issues whereas boys like topics outside their direct experience (Loh, 2007). Aware of such trends, teachers need to intervene and encourage the two genders to widen the blogging targets. They can also contribute to websites by pasting examples of good Chinese and English usage. Computers can have a beneficial impact on students' reading but only if computer usage is well targeted and does not consist of students playing repetitive games. Importantly, the trend for students to use information technology out of school should not be ignored. Such spontaneous communication by students should be analysed and teachers should plan lesson input to refine the language used by students in blogs to good effect in terms of literacy development. Parents need to be given support about how to guide students into using technology to maximum effect outside school so that blogging becomes a vehicle for literacy learning and growth.

\section{Acknowledgments}

The authors thank the Research Grant Council of Hong Kong SAR for its support through CERG research grant HKU 7449/06H. They thank the children, their parents, teachers and school principals in the 66 primary schools in Hong Kong for their participation in the project. The authors would like to thank Dr Terry Dolan for his invaluable input into this paper. 


\section{References}

Bartlett-Bragg, A. (2003). Blogging to learn. The Knowledge Tree, Edition Four, 2003. http:/ / www.flexiblelearning.net.au/knowledgetree/ edition04/pdf/Blogging_to_Learn.pdf [viewed 18 Mar 2009, verified 20 Mar 2010]

Barger, J. (1997). Robot Wisdom weblog. http: / / www.robotwisdom.com/ [viewed 18 Feb 2010]

Bausch, P., Haughey, M. \& Hourihan, M. (2002). We blog: Publishing online with weblogs. New York: John Wiley \& Sons, (Chapter 8).

Blood, R. (2000). Weblogs: A history and perspective. From Rebecca's Pocket. http: / / www.rebeccablood.net/essays / weblog_history.html [viewed 18 Mar 2009]

Blood, R. (2002). The weblog handbook: Practical advice on creating and maintaining your blog. Cambridge MA: Perseus Publishing.

Bullock, A. (1975). A language for life. Report of a Commission of Enquiry appointed under the Chairmanship of Sir Alan Bullock. London: HMSO.

Campbell, J. R., Kelly, D. L., Mullis, I. V. S., Martin, M. O. \& Sainsbury, M. (2001). Framework and specifications for PIRLS assessment 2001 (2nd ed.). Chestnut Hill, MA: Boston College. [verified 6 Apr 2010] http: / / timss.bc.edu / pirls2001i / PIRLS2001_Pubs_AF.html

Census and Statistics Department (2007). Thematic Household Survey Report No. 32: Information Technology Usage and Penetration. Hong Kong, Census and Statistics Department, HKSAR Government.

Census and Statistics Department (2008). Thematic Household Survey Report No. 37: Information Technology Usage and Penetration. Hong Kong, Census and Statistics Department, HKSAR Government.

Chen, X. D., Wang, X. H., Gao, D. D. \& Zhang, Z. P. (2003). Blogging culture and modern educational technology. e-Education Research, 119, 17-21.

Chen, X. D. \& Zhang, Z. P. (2003). The application of blog on education: A phenomenology perspective. http:/ / buidingandbird.blog.hexun.com/2546195_d.html [viewed 15 Mar 2009; in Chinese]

Conhaim, W. W. (2002). Blogging: What is it? Link-Up (USA), 19(3), 3-8.

Ferdig, R. E., \& Trammell, K. D. (2004). Content delivery in the 'Blogosphere'. THE Journal, February 2004. http: / / thejournal.com/ articles / 2004/ 02/01/ content-delivery-in-theblogosphere.aspx?sc_lang=en [viewed 25 Mar 2009, verified 20 Mar 2010]

Loh, E. K. Y. (2007). A research on Hong Kong pupils' emotional expression in Chinese writing. Unpublished doctoral thesis, The University of Hong Kong, Hong Kong.

Merholz, P. (2002). Play with your words. peterme.com, 17 May. [viewed 25 Mar 2009, verified 22 Mar 2010] http: / / www.peterme.com/archives/00000205.html

Mullis, I. V. S., Martin, M. O., Gonzalez, E. J. \& Kennedy, A. M. (2003). PIRLS 2001 International Report. Chestnut Hill, MA: Boston College, PIRLS International Study Centre. [verified 6 Apr 2010] http:/ / timss.bc.edu/pirls2001i/PIRLS2001_Pubs_IR.html

Mullis, I. V. S., Kennedy, A. M., Martin, O. M. \& Sainsbury, M. (2006). Progress in International Reading Literacy Study (PIRLS) 2006: Assessment framework and specifications (2nd ed.). Chestnut Hill, MA: Boston College, PIRLS International Study Centre. [verified 6 Apr 2010] http: / / timss.bc.edu / pirls2006/ framework.html

Nardi, B. A., Schiano, D. J., Gumbrecht, M., \& Swartz, L. (2003). "I'm blogging this" A closer look at why people blog. http:/ / www.ics.uci.edu/ ipd/classes/ics234cw04/nardi.pdf [viewed 14 Mar 2009, verified 22 Mar 2010 at http:/ / home.comcast.net/ diane.schiano/Blog.draft.pdf] 
Oravec, J. A. (2002). Bookmarking the world: Weblog applications in education. Journal of Adolescent \& Adult Literacy, 45(7), 616-621.

Paquet, S. (2003). Personal knowledge publishing and its uses in research. KnowledgeBoard, 10 January [viewed 18 Mar 2009, verified 20 Mar 2010] http: / / www.knowledgeboard.com/item/ 253

Sim, S. H. (2008). The use of blogging to enhance the learning of Chinese writing in secondary school students in Singapore. Unpublished Ph.D. Thesis. Hong Kong. The University of Hong Kong. [verified 22 Mar 2010] http:/ / hub.hku.hk/handle/123456789/51187

Song, H. S. Y. \& Chan, Y. M. (2008). Educational blogging: A Malaysian university students' perception and experience. In Hello! Where are you in the landscape of educational technology? Proceedings ascilite Melbourne 2008.

http: / / www.ascilite.org.au/conferences/melbourne07/ procs/ song.pdf

Tan, Y. H., Teo, E. H., Aw, W.L. \& Lim, W. Y. (2005). Portfolio building in Chinese language learning using blogs. In Proceedings BlogTalk Downunder 2005 Conference, Sydney, Australia, 19-22 May. [viewed 25 Mar 2009, verified 20 Mar 2010]

http: / / edublog.net/files/papers / portfolio_building_in_cl_learning_using_blogs.pdf

Tan, Y. H., Ow, J. E. G. \& Ho, J. M. P. Y. (2005). Weblogs in education. From IT literature review, Education Technology Division. [verified 20 Mar 2010] http: / / www.edublog.net/ files / papers / weblogs\%20in\%20education.pdf

Tse, S. K., Lam, J. W. I., Lam, R. Y. H. \& Loh, E. K. Y. (2003). PIRLS 2001: Hong Kong component. Chinese Language Testing, 4, 1-9.

Tse, S. K., Lam, J. W. I., Lam, R. Y. \& Loh, E. K. Y. (2006). Learn to read: The performance of Hong Kong primary 4 students in PIRLS 2001. Hong Kong: Hong Kong University Press.

Ward, J. M. (2004). Blog assisted language learning (BALL): Push button publishing for the pupils. TEFL Web Journal, 3(1). [verified 20 Mar 2010] http:/ / www.espworld.info/Articles_26/push\%20button\%20publishing\%20ward\%202004.pdf

Wu, J. B., Chen, Y. H. (2006). The application of blog in case teaching - An exploratory study. Journal of Information Management - Concepts, Systems, and Applications, 8(2), 65-84. [verified 20 Mar 2010; Chinese with English abstract and references] http: / /jim.im.tku.edu.tw/ fulltext/ 8-2/4.pdf

Professor Shek-kam Tse (corresponding author)

The University of Hong Kong, Faculty of Education

Pokfulam, Hong Kong SAR.

Email: sktse@hkucc.hku.hk Web: http:/ / www.hku.hk/curric/sktse

Dr Allan Hoi-kau Yuen, Associate Professor

The University of Hong Kong, Faculty of Education

Email: hkyuen@hkucc.hku.hk Web: http: / / people.cite.hku.hk/hkyuen

Dr Elizabeth Ka-yee Loh, Assistant Professor

The University of Hong Kong, Faculty of Education

Email: ekyloh@hkucc.hku.hkWeb: http: / / www.hku.hk/ekyloh

Mr Joseph Wai-ip Lam, Assistant Professor

The University of Hong Kong, Faculty of Education

Email: jwilam@hkucc.hku.hk Web: http: / / www.hku.hk/curric/lamwi

Mr Rex Hung-wai Ng, Senior Research Assistant

The University of Hong Kong, Faculty of Education 